\title{
EFFECTS OF PLANT REGULATORS ON THE GROWTH AND FLOWERING OF SAINT AUGUSTINE GRASS PLANTS
}

\author{
EFEITO DE INIBIDORES VEGETAIS SOBRE O CRESCIMENTO E O \\ FLORESCIMENTO DA GRAMA-SANTO-AGOSTINHO
}

\section{Sidnei Roberto de MARCHI ${ }^{1}$; Dagoberto MARTINS ${ }^{2}$; Neumárcio Vilanova da COSTA ${ }^{3}$;}

1. Professor, Doutor, Universidade Federal de Mato Grosso - UFMT, Barra do Garças, MT, Brasil. Sidneimarchi.ufmt@ gmail.com; 2. Professor, Doutor, Faculdade de Ciências Agrárias e Veterinárias - FCAV, Universidade Estadual Paulista - UNESP, Jaboticabal, SP, Brasil; 3. Professor, Doutor, Centro de Ciências Agrárias, Universidade Estadual do Oeste do Paraná - UNIOESTE, Marechal Cândido Rondon, PR, Brasil.

\begin{abstract}
The objective of this work was to evaluate the effects of three plant growth inhibitors on the development and emission of floral rachis of Saint Augustine grass [Stenotaphrum secundatum (Walt.) Kuntzel] plants. The study was carried out in a 15 month old lawn with the experimental plots being distributed in accordance with a complete randomized block design with four replications. The treatments consisted of sole application of trinexapac-ethyl $\left(113,226,452,678\right.$, and $\left.904 \mathrm{~g}_{\text {ai ha }}{ }^{-1}\right)$, prohexadione-calcium (100 and $\left.200 \mathrm{~g}_{\text {ai ha }} \mathrm{a}^{-1}\right)$, and bispyribac-sodium (40 and $60 \mathrm{~g}$ ai ha ${ }^{-1}$ ) plus a check treatment in which the plants were not submitted to any of the plant growth inhibitors. The effects of those products were evaluated in terms of visual signs of plant intoxication, plant height, emission and height of floral rachises, and chip total dry matter production. All the plant growth inhibitors resulted in visible injury to the plants but these intoxication signs practically disappeared 28 days after the application. Trinexapac-ethyl at the dose of $904 \mathrm{~g}_{\text {ai }} \mathrm{ha}^{-1}$ reduced plant height by $59.7 \%$, the emission of floral rachis by $96.4 \%$, and the amount of chip dry matter production by 87.7\%. Plant growth inhibitors may reduce the number of times of lawn plants cutting up to 119 days after their application with no harmful effects on the plants visual aspect.
\end{abstract}

KEYWORDS: Stenotaphrum secundatum. trinexapac-ethyl. prohexadione-calcium. bispyribac-sodium

\section{INTRODUCTION}

Saint Augustine ( $S$. secundatum) grass had its origin point in Central Europe although some investigators claim it to be from the American continent (DUBLE, 2004). Its hairless blue-green leaves are found at the top of the stems, in a distichal position which confers the lawns a beautiful and velvety aspect (CASLER; DUNCAN, 2003; REYNOLDS et al., 2009).

According to Reynolds et al (2009), the Saint Augustine grass does not demand a lot of care for its growth but it is demanding of medium to highly fertile and well drained soils and conditions of plain luminosity. According to these authors, the Saint Augustine plants produce a large amount of biomass when growing under the aforementioned conditions thus needing to be weekly trimmed during the growth season to keep the lawns with good visual quality.

On the other hand, Trenholm; Cisar and Hunru (2000) report that the repeated cutting operations may cause plant reduction of vigor and density due to the fact that these plants have no rhizomes. In addition to that, the dilacerations of the leaves by the rotating laminas of the cutting machine cause the plants to develop a bronze color and, if the chips resulting from the plants cutting are not remove, they may give shelter to pests and diseases.

Another important fact affecting a lawn visual aspect is the emission of a high number of rachides at the beginning of the reproductive phase. These rachises display different color patterns that don't go with the color of leaves. In addition, both leaves and rachises may reach excessive heights causing discomfort for the lawn users (MARCHI; MARTINS; McELROY, 2013).

Plant growth inhibitors may help to reduce the number of plant cuttings. This is already a common practice in the management of lawns in the United States where Type 1 plant growth inhibitors such as mefluidide and ethephon, which inhibit cell division, and also of Type II, such as trinexapacethyl, prohexadione-calcium, and paclobutrazol (McCULLOUGH et al., 2004; ERVIN; ZHANG, 2007), which inhibit cell elongation. Type II inhibitors are capable of modifying plant hormone concentration and promote slight leaf area expansions and also the development of lateral plant structures without causing the undesirable increments in vertical growth (McCULLOUGH et al., 2004). 
Effects of plant regulators...

Undesirable effects though are likely to occur when those plant growth inhibitors are not properly applied. The leaf injury types vary with environmental conditions if under temperate climatic conditions - dark green spots occur (ERVIN; KOSKI, 2001; HECKMAN et al., 2005; McCULLOUGH et al., 2006); if under tropical conditions, a yellowish discoloring is likely to occur (HECKMAN, HORST; GAUSSOIN, 2001; McCULLOUGH et al., 2005; McCARTY et al., 2011).

In addition, to reducing plant vegetative growth, Type I inhibitors are also efficient in suppressing the emission of floral emissions, and Type II inhibitors though are not efficient in suppressing floral emissions (JOHNSON, 1990; FRY, 1991; MITTLESTEADT et al., 2009).

So, the aim of the present research was to verify the effects of doses of the plant growth
MARCHI, S. R.; MARTINS, D.; COSTA, N. V.

inhibitors trinexapac-ethyl, prohexadione-calcium, and bispyribac-sodium on the vegetative and reproductive growth of Saint Augustine grass plants.

\section{MATERIAL AND METHODS}

The experimental area where the experiment was carried out has the following geographical coordinates: $22^{\circ} 07^{\prime} 56^{\prime \prime}$ of South latitude and $74^{\circ}$ 66' 84' 'WGr. of longitude and a height of $760 \mathrm{~m}$ above sea level. The 15 month old lawn was formed by Saint Augustine grass carpets in a sprinkler irrigated area. The soil of the area was classified as a typical A moderate distroferric red Nitossolo (EMBRAPA, 2006) with a clayish structure. After the application of $2.6 \mathrm{t}$ of lime per hectare, the soil chemical analysis showed the results in Table 1.

Table 1. Soil chemical properties after liming and prior to the experiment $(0-20 \mathrm{~cm}$ deep).

\begin{tabular}{|c|c|c|c|c|c|c|c|c|c|c|}
\hline $\begin{array}{c}\mathrm{pH} \\
\mathrm{CaCl}_{2}\end{array}$ & C org. & $\mathrm{P}$ & $\mathrm{Ca}$ & $\mathrm{Mg}$ & K & $\mathrm{Al}$ & $\mathrm{H}+\mathrm{Al}$ & CTC & V & $\mathrm{Fe}_{2} \mathrm{O}_{3}$ \\
\hline$\left(0,01 \mathrm{~mol} \mathrm{~L}^{-1}\right)$ & $\mathrm{g} \mathrm{kg}^{-1}$ & $\mathrm{mg} \mathrm{kg}^{-1}$ & $-\cdots$ & -.--.. & -.-.. & $\mathrm{ol}_{\mathrm{c}} \mathrm{kg}$ & 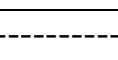 & ---- & $\%$ & $\mathrm{~g} \mathrm{~kg}^{-1}$ \\
\hline 5,9 & 15 & 12 & 27 & 13 & 9,6 & 0,3 & 32,9 & 82,9 & 60 & 176 \\
\hline
\end{tabular}

The lawn height was kept at $3,0 \mathrm{~cm}$ above soil surface by means of successive cuttings with the help of a motorized mechanical cutter with rotating laminas and a special chip collector.

The experimental plots were distributed in the field according to a randomized complete block design with four repetitions. The treatments consisted of sole applications of the plant growth inhibitors trinexapac-ethyl at the doses of 113,226 , 452,678 , and $904 \mathrm{~g}$ ai ha ${ }^{-1}$, prohexadione-calcium at the doses of 100 and $200 \mathrm{~g}$ ai ha ${ }^{-1}$, and bispyribacsodium at the doses of 40 and $60 \mathrm{~g}$ ai ha ${ }^{-1}$. A check treatment in which the plants were not treated with the mentioned growth inhibitors was also considered. The total area of each plot was of 3.75 $\mathrm{m}^{2}$ ( $1.5 \mathrm{~m}$ wide X $2.5 \mathrm{~m}$ long). A $0.5 \mathrm{~m}^{2}$ band at the side of each plot was kept untreated so as to improve the visualization of the injuries caused by the products.

The application of the products was accomplished by means of a $\mathrm{CO}_{2}$ pressure trailed field sprayer with two flat spray nozzles (TP $8002 \mathrm{VS}$ ) spaced of $50 \mathrm{~cm}$ on the spray boom. The whole equipment was kept at a constant pressure of 2.0 bar so as to result in a constant consumption of $200 \mathrm{~L} \mathrm{ha}^{-1}$ of the product.
The products were applied at the end of January under partly clouded conditions, air temperature of $26.3{ }^{\circ} \mathrm{C}$ and air relative humidity of $69 \%$, wind blasts of $9.0 \mathrm{~km} \mathrm{~h}^{-1}$ moving in the SE direction. During applications, each plot was laterally protected by a partition wall to avoid the products to drift from one plot to an adjacent one. The study was carried out from January to the beginning of May, a period in which environmental conditions favoring Saint Augustine grass plants growth are prevalent in the area.

Plant injury and growth reduction were weekly evaluated up to the middle of April since after this moment, due to air temperature and length of the day reductions (which are characteristics of this period of the year in the area where the experiment was run), both treated and untreated Saint Augustine plants showed no further alterations in height.

Plant injuries brought about by the products were visually evaluated with the help of a $0-100 \%$ scale in which 0 represented no visible injury and 100 a dead plant. Plant height, referred to distance form soil surface and the horizontal line of medium leaf top, was expressed in centimeters as indicated by a common rule. The number and height of inflorescences were evaluated by using a metal 
square of $0.50 \times 0.50 \mathrm{~cm}\left(0.25 \mathrm{~m}^{2}\right)$ lanced randomly in the central middle of each plot.

In all plots the plants were trimmed with the help of a mechanical cutter at the end of the experiment. The resulting chips were gathered, placed inside paper bags and kept in a forced ventilation oven at a constant temperature of $65{ }^{\circ} \mathrm{C}$ till a constant weight was reached. The chips were then weighed in a semi-analytical scale with a two decimal places precision and the read value used to calculate the total clippings dry matter (TCDM - g $\mathrm{m}^{-2}$ ). The TCDM values permitted to calculate the plants growth reduction percentage by means of the formula GR $(\%)=\left[\left(\mathrm{DMT}_{\mathrm{es}}-\mathrm{DMT}_{\mathrm{rt}}\right) \times 100\right] / \mathrm{DMT}_{\mathrm{es}}$ where $\mathrm{GR}=$ plant growth reduction, $\mathrm{DMT}_{\mathrm{es}}=$ check treatment plants dry matter, and $\mathrm{DMT}_{\mathrm{rt}}=$ treated plants dry matter with values expressed in percentage.
MARCHI, S. R.; MARTINS, D.; COSTA, N. V.

The results were submitted to the analysis of variance by the $\mathrm{F}$ test and when significance was verified, the means were compared by the Tukey test at the $5 \%$ level of probability.

\section{RESULTS AND DISCUSSION}

All growth inhibitors used provided considerable levels of visual injury in Saint Augustine grass plants at 7 days after application (DAA). The lowest level of injury was of $14 \%$ which resulted from the application of trinexapacethyl at the dose of $113 \mathrm{~g}_{\text {ai }} \mathrm{ha}^{-1}$. The toxic effect caused by this product increased as the doses grew up to $904 \mathrm{~g}$ ai ha ${ }^{-1}$ when injury level was of $58.7 \%$ (Table 2).

Table 2. Mean levels of visual injury observed in Saint Augustine grass plants treated with plant growth inhibitors

\begin{tabular}{|c|c|c|c|c|c|c|c|c|c|c|}
\hline \multirow{3}{*}{$\frac{\text { Treatement }\left(\mathrm{g} \text { ai ha }{ }^{-1}\right)}{\text { trinexapac-ethyl } 113}$} & \multicolumn{10}{|c|}{ Injury $(\%)-\mathrm{DAA}^{\underline{1}}$} \\
\hline & \multicolumn{2}{|c|}{7} & \multicolumn{2}{|c|}{14} & \multicolumn{2}{|c|}{21} & \multicolumn{2}{|c|}{28} & \multicolumn{2}{|c|}{56} \\
\hline & 14.0 & $\mathrm{~cd}$ & 12.5 & de & 4.0 & $\mathrm{bc}$ & 0.0 & $\mathrm{c}$ & 0.0 & $\mathrm{c}$ \\
\hline trinexapac-ethyl 226 & 19.9 & $\mathrm{~cd}$ & 16.9 & $\mathrm{~cd}$ & 6.1 & $\mathrm{~b}$ & 0.0 & $\mathrm{c}$ & 0.0 & $\mathrm{c}$ \\
\hline trinexapac-ethyl 452 & 30.8 & bc & 27.5 & $\mathrm{c}$ & 12.8 & $\mathrm{a}$ & 7.9 & $\mathrm{~b}$ & 7.7 & $\mathrm{~b}$ \\
\hline trinexapac-ethyl 678 & 48.0 & $a b$ & 43.8 & $\mathrm{~b}$ & 13.7 & $\mathrm{a}$ & 8.3 & $a b$ & 8.5 & $\mathrm{ab}$ \\
\hline trinexapac-ethyl 904 & 58.7 & $\mathrm{a}$ & 57.5 & $\mathrm{a}$ & 15.0 & $\mathrm{a}$ & 10.7 & $\mathrm{a}$ & 9.8 & $\mathrm{a}$ \\
\hline prohexadione-calcium 100 & 15.0 & $\mathrm{~cd}$ & 13.7 & $d$ & 0.0 & $\mathrm{c}$ & 0.0 & $\mathrm{c}$ & 0.0 & $\mathrm{c}$ \\
\hline prohexadione-calcium 200 & 19.5 & $\mathrm{~cd}$ & 17.5 & $\mathrm{~cd}$ & 4.0 & $\mathrm{bc}$ & 0.0 & $\mathrm{c}$ & 0.0 & $\mathrm{c}$ \\
\hline bispyribac-sodium 40 & 20.3 & $\mathrm{~cd}$ & 18.8 & $\mathrm{~cd}$ & 0.0 & $\mathrm{c}$ & 0.0 & $\mathrm{c}$ & 0.0 & $\mathrm{c}$ \\
\hline bispyribac-sodium 60 & 23.0 & $\mathrm{c}$ & 21.3 & $\mathrm{~cd}$ & 1.3 & $\mathrm{c}$ & 0.0 & $\mathrm{c}$ & 0.0 & $\mathrm{c}$ \\
\hline Control & 0.0 & $\mathrm{~d}$ & 0.0 & e & 0.0 & $\mathrm{c}$ & 0.0 & $\mathrm{c}$ & 0.0 & $\mathrm{c}$ \\
\hline F Treatment & \multicolumn{2}{|c|}{$16.39 * *$} & \multicolumn{2}{|c|}{$37.65 * *$} & \multicolumn{2}{|c|}{$45.88 * *$} & \multicolumn{2}{|c|}{$71.34 * *$} & \multicolumn{2}{|c|}{$152.20 * *$} \\
\hline F Block & \multicolumn{2}{|c|}{$4.34^{*}$} & \multicolumn{2}{|c|}{$5.15^{* *}$} & \multicolumn{2}{|c|}{$1.51^{\mathrm{NS}}$} & \multicolumn{2}{|c|}{$1.09^{\mathrm{NS}}$} & \multicolumn{2}{|c|}{$1.13^{\mathrm{NS}}$} \\
\hline $\mathrm{SMD}^{12}$ & \multicolumn{2}{|c|}{20.56} & \multicolumn{2}{|c|}{13.11} & \multicolumn{2}{|c|}{4.32} & \multicolumn{2}{|c|}{2.53} & \multicolumn{2}{|c|}{1.66} \\
\hline $\mathrm{CV}^{\underline{1}}(\%)$ & \multicolumn{2}{|c|}{33.89} & \multicolumn{2}{|c|}{23.47} & \multicolumn{2}{|c|}{31.16} & \multicolumn{2}{|c|}{38.67} & \multicolumn{2}{|c|}{26.28} \\
\hline
\end{tabular}

NS - non significant $* *$ Significant at the level of $1 \%$ of probability $*$ Significant at the level of $5 \%$ of probability. Means in the same column, followed by the same letter, are not significantly different at the $5 \%$ level of probability, according to the Tukey test; $\backslash 1$ - DAA - days after application; $\underline{2}-$ SMD - Significant mean deviation; $\underline{1}-\mathrm{CV}-$ Coefficient of variation.

Plant injury was also visually perceptible when prohexadione-calcium was applied at the doses of 100 and $200 \mathrm{~g}_{\text {ai }} \mathrm{ha}^{-1}$ with respective levels of injury of 15 and $19 \%$ at 7 DAA. Bispyribacsodium at the doses of 40 and $60 \mathrm{~g}$ ai ha ${ }^{-1}$ resulted in toxicity levels similar to those caused by the lowest doses of trinexapac-ethyl and of prohexadionecalcium since the levels of injury detected 7 DAA were of values close to $20 \%$ (Table 2).

It is important to emphasize that although the injury levels caused by trinexapac-ethyl at the doses of 113 and $226 \mathrm{~g}$ ai ha ${ }^{-1}$, prohexadione- calcium at 100 and $200 \mathrm{~g}$ ai ha ${ }^{-1}$, and by bispyribacsodium at $40 \mathrm{~g}$ ai ha ${ }^{-1}$ were statistically similar to those of the check treatment plants, they may be considered as unacceptable if lawns with good visual aspect are to be the objective (FAGERNESS; YELVERTON, 2000; McCARTY et al., 2004; McCULLOUGH et al., 2007).

The injury levels remained relatively high when plant evaluation was made 14 DAA and that only at 21 DAA the visual symptoms started to fade away. Toxicity symptoms for all treatments practically disappeared 28 DAA with the exception 
of trinexapac-ethyl at the doses of 452, 678, and 904 $\mathrm{g}$ ai ha ${ }^{-1}$ with injury levels respectively of $7.9,8.3$, and $10.7 \%$, which had almost no variation till the last evaluation at 56 DAA (Table 2).

McCarty et al. (2004) observed that different doses of trinexapac-ethyl also caused visual injuries in Saint Augustine plants two weeks after the application thus bringing about a quality reduction in the lawn. These authors also mention that the injuries remained visible for an additional period of two weeks after application.

The injury caused by the plant growth inhibitors was characterized by chlorosis and the drying of the leaf blade tip these symptoms giving the lawns a discolored aspect. These symptoms are apparently related to the interruption of the synthesis of gibberellins and this in association with the high temperatures of tropical regions induces the liberation of ethylene in the plants (TAIZ; ZEIGER, 2004).

Research works have shown that the deleterious effects of trinexapac-ethyl and bispyribac-sodlium may be promptly reversed by a supplemental dose of iron or nitrogen since these elements are important for chlorophyll synthesis which restores the green color to the grass plants (JOHNSON, 1997; ZHANG et al., 2002; ERVIN et al., 2004; MARCHI; MARTINS; McELROY, 2013). In this study, the rapid recovery of the green color by the Saint Augustine plants is probably due to the high levels with which iron was verified to occur in the soil of this experiment according to results of the chemical analysis; iron was found at the level of $176 \mathrm{~g}$ of iron oxide $\left(\mathrm{Fe}_{2} \mathrm{O}_{3}\right) \mathrm{kg}^{-1}$.

The vegetative vertical growth of the Saint Augustine grass plant was significantly affected by the growth inhibitors starting from 14 DAA onwards in comparison with the check treatment. Plant height was affected until they were 119 days old, when plant height evaluations were interrupted since the check plants underwent no further alteration due to the reductions in temperature and luminosity taking place at that time of the year (Table 3).

It is important to emphasize that all the doses of trinexapac-ethyl, prohexadione-calcium at $200 \mathrm{~g}$ ai ha ${ }^{-1}$ and bispyribac-sodium at $60 \mathrm{~g}$ ai ha ${ }^{-1}$ resulted in plant height reduction of the order of 50 to $60 \%$. The smallest reductions resulted from prohexadione-calcium and bispyribac-sodium applied at the respective doses of 100 and $40 \mathrm{~g}$ ai ha ${ }^{1}$ which were, respectively, of 49.6 and $38.9 \%$ at 119 DAA (Table 3).
MARCHI, S. R.; MARTINS, D.; COSTA, N. V.

Fagerness and Yelverton (2000) reported that the inhibition period shown by Tifway bermudagrass plants lasted between 2 and 4 weeks when they were submitted to sole doses of 71 and $107 \mathrm{~g}$ ai ha ${ }^{-1}$, respectively.

McCullough et al. (2007) verified that golf balls would roll $25 \mathrm{~cm}$ longer distances in comparison with the check treatment when Dwarf Bermudagrass (Cynodon dactylon $X \quad C$. transvaalensis ) plants were treated with trinexapacethyl at the doses of 17,33 , and $50 \mathrm{~g}$ ai ha ${ }^{-1}$ applied during a period of three months at intervals of one, two, and three weeks, respectively.

Marchi et al. (2013) observed that two sequential applications of prohexadione-calcium at the dose of $200 \mathrm{~g}$ ai ha ${ }^{-1}$ or bispyribac-sodium at 60 $\mathrm{g}$ ai ha ${ }^{-1}$ led Meyer zoysiagrass (Zoysia japonica Steud.) plants height reductions of respectively 46 and $45 \%$ during a period of 110 DAA.

McCarty et al. (2004) applied trinexapacethyl at the doses of 140 and $290 \mathrm{~g}$ ai ha ${ }^{-1}$ which resulted in Saint Augustine plant height reductions of approximately $50 \%$ for a period of 4 weeks after the application. The results reported by McCarty et al (2004) are similar to those reported in this study.

All the plant growth inhibitors used in this study were verified to bring about significant reductions in inflorescence height at 119 DAA in comparison with the plants of the check treatment. The lowest value resulted when trinexapac-ethyl was applied at the dose of $904 \mathrm{~g}_{\text {ai ha }}{ }^{-1}$ when the inflorescence height was of $2.9 \mathrm{~cm}$. Inflorescence height was close to $6.0 \mathrm{~cm}$ when trinexapac-ethyl was applied at the doses of 226, 452, and $678 \mathrm{~g}$ ai $\mathrm{ha}^{-1}$ and superior to $7.3 \mathrm{~cm}$ at the dose of $113 \mathrm{~g}$ ai $\mathrm{ha}^{-1}$ and for the other products and doses. Inflorescence height in the check treatments was of $20.6 \mathrm{~cm}$ (Table 4).

The number of inflorescences Saint Augustine plants emitted was also reduced by the plant growth inhibitors : table 4 shows that trinexapac-ethyl at the doses of 226, 452, 678, and $904 \mathrm{~g}$ ai ha ${ }^{-1}$, prohexadione-calcium at the doses of 100 and $200 \mathrm{~g}$ ai ha ${ }^{-1}$, and bispyribac-sodium at the dose of $60 \mathrm{~g}$ ai ha ${ }^{-1}$ resulted in the highest reduction values in the number of floral rachises emitted in all treatments, floral rachis numbers were significantly smaller than the one of the check treatment, that is, 233.8 inflorescences $\mathrm{m}^{-2}$. 
Table 3. Saint Augustine grass plant height and respective height reduction resulting from their being treated with plant growth inhibitors.

\begin{tabular}{|c|c|c|c|c|c|c|c|c|c|c|c|c|c|c|c|c|c|}
\hline \multirow{3}{*}{$\frac{\text { Treatment }\left(\mathrm{g}_{\text {ai ha }}{ }^{-1}\right)}{\text { trinexapac } 113}$} & \multicolumn{16}{|c|}{ Plant height $(\mathrm{cm})-\mathrm{DAA}^{\mathbb{I}}$} & \multirow{3}{*}{$\begin{array}{c}\begin{array}{c}\text { Reductions } \\
(\%)^{12}\end{array} \\
50.4\end{array}$} \\
\hline & \multicolumn{2}{|c|}{7} & \multicolumn{2}{|c|}{14} & \multicolumn{2}{|c|}{21} & \multicolumn{2}{|c|}{28} & \multicolumn{2}{|c|}{42} & \multicolumn{2}{|c|}{56} & \multicolumn{2}{|c|}{90} & \multicolumn{2}{|c|}{119} & \\
\hline & 4.3 & $\mathrm{ab}$ & 5.1 & $\mathrm{a}$ & 6.0 & $\bar{a}$ & 6.8 & $\mathrm{a}$ & 7.1 & $\mathrm{a}$ & 7.1 & $\mathrm{a}$ & 7.4 & $\mathrm{a}$ & 7.5 & $\bar{a}$ & \\
\hline trinexapac 226 & 3.7 & $\mathrm{~b}$ & 4.8 & $\mathrm{a}$ & 5.4 & a & 5.4 & a & 6.4 & a & 6.7 & a & 7.1 & a & 7.2 & a & 52.1 \\
\hline trinexapac 452 & 3.5 & $\mathrm{~b}$ & 4.9 & $\mathrm{a}$ & 5.1 & a & 5.2 & a & 6.3 & a & 6.6 & a & 6.7 & a & 6.9 & a & 54.3 \\
\hline trinexapac 678 & 3.2 & $\mathrm{~b}$ & 3.9 & $\mathrm{a}$ & 5.5 & a & 5.9 & a & 5.9 & $\mathrm{a}$ & 6.4 & $\mathrm{a}$ & 6.5 & $\mathrm{a}$ & 6.8 & $\mathrm{a}$ & 55.0 \\
\hline trinexapac 904 & 3.9 & $a b$ & 4.1 & $\mathrm{a}$ & 4.4 & $\mathrm{a}$ & 4.6 & $\mathrm{a}$ & 5.0 & $\mathrm{a}$ & 5.0 & $\mathrm{a}$ & 5.7 & $\mathrm{a}$ & 6.1 & $\mathrm{a}$ & 59.7 \\
\hline prohexadione 100 & 4.2 & $\mathrm{ab}$ & 4.9 & $\mathrm{a}$ & 5.1 & $\mathrm{a}$ & 5.6 & $\mathrm{a}$ & 5.6 & $\mathrm{a}$ & 6.0 & $\mathrm{a}$ & 7.2 & $\mathrm{a}$ & 7.6 & $\mathrm{a}$ & 49.6 \\
\hline prohexadione 200 & 4.1 & $a b$ & 4.6 & $\mathrm{a}$ & 4.7 & $\mathrm{a}$ & 4.7 & $\mathrm{a}$ & 4.7 & $\mathrm{a}$ & 5.6 & $\mathrm{a}$ & 7.0 & $\mathrm{a}$ & 7.5 & $\mathrm{a}$ & 50.4 \\
\hline bispyribac 40 & 3.4 & $\mathrm{~b}$ & 3.7 & $\mathrm{a}$ & 4.0 & $\mathrm{a}$ & 4.2 & $\mathrm{a}$ & 4.9 & $\mathrm{a}$ & 6.9 & $\mathrm{a}$ & 8.9 & $\mathrm{a}$ & 9.3 & a & 38.9 \\
\hline bispyribac 60 & 3.2 & $a b$ & 3.6 & $\mathrm{a}$ & 3.9 & $\mathrm{a}$ & 4.4 & $\mathrm{a}$ & 4.7 & $\mathrm{a}$ & 6.0 & $\mathrm{a}$ & 7.1 & $\mathrm{a}$ & 7.2 & $\mathrm{a}$ & 52.3 \\
\hline Control & 6.5 & $\mathrm{c}$ & 8.4 & $\mathrm{~b}$ & 9.6 & $\mathrm{~b}$ & 11.9 & $\mathrm{~b}$ & 13.6 & $\mathrm{~b}$ & 14.5 & $\mathrm{~b}$ & 15.1 & $\mathrm{~b}$ & 15.1 & $\mathrm{~b}$ & \\
\hline F Treatment & \multicolumn{2}{|c|}{$2.82 *$} & \multicolumn{2}{|c|}{$5.32 *$} & \multicolumn{2}{|c|}{$6.18^{* *}$} & \multicolumn{2}{|c|}{$11.06^{* *}$} & \multicolumn{2}{|c|}{$17.27 * *$} & \multicolumn{2}{|c|}{$20.77 * *$} & \multicolumn{2}{|c|}{$7.94 * *$} & \multicolumn{2}{|c|}{$7.10 * *$} & \\
\hline F Block & \multicolumn{2}{|c|}{$3.42 *$} & \multicolumn{2}{|c|}{$8.46^{* *}$} & \multicolumn{2}{|c|}{$11.03 * *$} & \multicolumn{2}{|c|}{$4.85^{* *}$} & \multicolumn{2}{|c|}{$5.59 * *$} & \multicolumn{2}{|c|}{$11.35^{* *}$} & \multicolumn{2}{|c|}{$13.13 * *$} & \multicolumn{2}{|c|}{$12.38 * *$} & \\
\hline $\mathrm{SMD}^{13}$ & \multicolumn{2}{|c|}{2.78} & \multicolumn{2}{|c|}{2.98} & \multicolumn{2}{|c|}{3.21} & \multicolumn{2}{|c|}{3.28} & \multicolumn{2}{|c|}{3.24} & 2. & & 4. & & & & \\
\hline $\mathrm{CV}^{14}(\%)$ & & & & & & & & & 21 & & 16 & & 24 & & & & \\
\hline
\end{tabular}

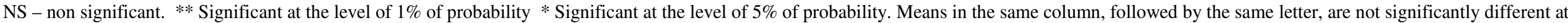

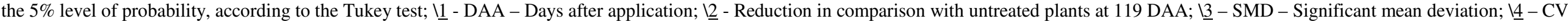

- Coefficient of variation. 
Table 4. Plant height, number of inflorescences, and chips dry weight of Saint Augustine plants 119 days after the application of plant growth inhibitors.

\begin{tabular}{|c|c|c|c|c|c|c|c|c|}
\hline \multirow{3}{*}{$\frac{\text { Treatment }\left(\mathrm{g} \text { ai ha }{ }^{-1}\right)}{\text { trinexapac-ethyl } 113}$} & \multicolumn{5}{|c|}{ Inflorescence } & \multicolumn{3}{|c|}{$\mathrm{TCDM}^{1 !}$} \\
\hline & \multicolumn{2}{|c|}{ Height $(\mathrm{cm})$} & \multicolumn{2}{|c|}{ Number $\left(\mathrm{m}^{-2}\right)$} & \multirow{2}{*}{$\begin{array}{r}\% \\
49.2\end{array}$} & \multirow[t]{2}{*}{$\left(\mathrm{g} \mathrm{m}^{-2}\right.$} & \multicolumn{2}{|c|}{ GR $(\%)$} \\
\hline & 8.5 & $\mathrm{bc}$ & 118.7 & $\mathrm{~b}$ & & & $\mathrm{bc}$ & 59.3 \\
\hline & & & & & & 262.9 & & \\
\hline trinexapac-ethyl 226 & 6.2 & bcd & 40.8 & $\mathrm{~cd}$ & 82.5 & 190.1 & $\mathrm{~cd}$ & 70.6 \\
\hline trinexapac-ethyl 452 & 5.9 & $\mathrm{~cd}$ & 18.6 & $\mathrm{~cd}$ & 92.0 & 124.4 & de & 80.8 \\
\hline trinexapac-ethyl 678 & 5.7 & $\mathrm{~cd}$ & 12.5 & $\mathrm{~cd}$ & 94.6 & 74.4 & $\mathrm{e}$ & 88.5 \\
\hline trinexapac-ethyl 904 & 2.9 & $\mathrm{~d}$ & 8.3 & $\mathrm{~d}$ & 96.4 & 79.5 & $\mathrm{e}$ & 87.7 \\
\hline prohexadione-calcium 100 & 10.1 & $\mathrm{~b}$ & 52.5 & $\mathrm{~cd}$ & 77.5 & 274.1 & $\mathrm{bc}$ & 57.6 \\
\hline prohexadione-calcium 200 & 8.3 & $\mathrm{bc}$ & 55.7 & $\mathrm{~cd}$ & 76.2 & 226.5 & bcd & 65.0 \\
\hline bispyribac-sodium 40 & 9.4 & $\mathrm{bc}$ & 59.0 & c & 74.8 & 325.3 & $\mathrm{~b}$ & 49.7 \\
\hline bispyribac-sodium 60 & 7.3 & $\mathrm{bc}$ & 32.2 & $\mathrm{~cd}$ & 86.2 & 305.2 & $\mathrm{~b}$ & 52.8 \\
\hline Control & 20.6 & $\mathrm{a}$ & 233.8 & $\mathrm{a}$ & - & 646.6 & a & \\
\hline F Treatment & \multicolumn{2}{|c|}{$32.05^{* *}$} & \multicolumn{3}{|c|}{$43.76^{\text {** }}$} & \multicolumn{3}{|c|}{$58.63^{* * *}$} \\
\hline F Block & \multicolumn{2}{|c|}{$1.43^{\mathrm{NS}}$} & \multicolumn{3}{|c|}{$7.84 * *$} & \multicolumn{3}{|c|}{$0.21^{\mathrm{NS}}$} \\
\hline $\mathrm{SMD}^{12}$ & \multicolumn{2}{|c|}{4.08} & \multicolumn{3}{|c|}{49.97} & \multicolumn{3}{|c|}{105.43} \\
\hline $\mathrm{CV}^{13}(\%)$ & \multicolumn{2}{|c|}{19.74} & \multicolumn{3}{|c|}{32.52} & \multicolumn{3}{|c|}{17.28} \\
\hline
\end{tabular}

NS - non significant $* *$ Significant at the level of $1 \%$ of probability $*$ Significant at the level of $5 \%$ of probability. Means in the same column, followed by the same letter, are not significantly different at the $5 \%$ level of probability, according to the Tukey test; $\underline{1}-$ Total clippings dry matter; $\underline{12}-\mathrm{SMD}-$ Significant mean deviation; $\underline{1} \underline{3}-\mathrm{CV}-$ Coefficient of variation.

It is important to highlight the fact that the highest reductions in the number of inflorescences was caused by the doses of 452, 678, and $904 \mathrm{~g}$ ai ha $^{-1}$ of trinexapac-ethyl, these reductions being respectively of $92,94.6$, and $96.4 \%$ of the number of inflorescences of the check treatment.

Several research works have shown that trinexapac-ethyl when sequentially applied to TifEagle bermudagrass plants may retard and/or reduce the emission of inflorescences and prolong the lawn visual aspect making unnecessary a new mechanical plant cutting (JOHNSON, 1990; FRY, 1991; COSTA et al., 2009; MITTLESTEADT et al., 2009). McCullough et al. (2007) reported a reduction of the order of $81 \%$ in the number of floral rachises when three doses equivalent to $50 \mathrm{~g}$ ai ha ${ }^{-1}$ of trinexapac-ethyl were applied at intervals of seven days on TifEagle bermudagrass (Cynodon dactylon $\times$ C. transvaalensis Burtt-Davy). Marchi et al. (2013) observed reductions higher than $76 \%$ in the number of floral axes of Meyer zoysiagrass (Zoysia japonica) when two applications of different doses of trinexapac-ethyl were sequentially applied at intervals of 14 days.

Johnson (1994) suggests that a plant growth inhibitor, to be commercially acceptable, should reduce the emission of floral rachises by at least $70 \%$. In this experiment, only trinexapac-ethyl applied at the lowest dose of $226 \mathrm{~g}$ ai ha ${ }^{-1}$ did not reduce floral rachis emission close to $70 \%$. On the other hand, the other doses of trinexapac-ethyl, prohexadione-calcium, and bispyribac-sodium resulted in floral rachis emission suppression higher than $74 \%$ (Table 4).

In the literature, information about the plant growth inhibitors of the Group II such as trinexapacethyl and prohexadione-calcium are that they are of little efficiency in suppressing floral rachis emission because they interfere in the biosynthesis of gibberellins and, consequently, on the reduction of cell elongation (JOHNSON, 1990; FRY, 1991; MITTLESTEADT et al., 2009; MARCHI; MARTINS; McELROY. 2013). On the other hand, the high levels of rachis emission suppression found in this study are probably due to the physiological alterations resulting from the different doses of the plant growth inhibitors used in this experiment (ERVIN; ZHANG, 2007).

The total chip dry matter (TCDM) at 119 DAA was significantly reduced by the different plant growth regulators and respective doses used in this experiment. The lowest amounts of chip resulted from the treatments in which trinexapacethyl was applied at the doses of 678 and $904 \mathrm{~g}$ ai $\mathrm{ha}^{-1}-74.4$ and $79.5 \mathrm{~g} \mathrm{~m}^{-2}$, respectively (Table 4). The amounts of dry weight resulting from the applied treatments (products and doses) were all lower than that of the check treatment plants, that is, 
Effects of plant regulators...

$646.6 \mathrm{~g} \mathrm{~m}^{-2}$ (Table 4). In Table 4 it is also possible to see that the TCDM reductions when both doses of trinexapac-ethyl were applied was superior to $87 \%$, this being an indication of how much plant mechanical cutting may be avoided.

Beam (2004) reported to have observed a direct relation between increasing sequential doses of prohexadione-calcium $(140+140,270+270$, $410+410,540+540$, and $670+670 \mathrm{~g}$ ai ha $\left.{ }^{-1}\right)$ and the percentage of reduction in chips total dry mass production in plants of Meyer zoysiagrass. The author also informs that the mass reductions were equivalent to the sequential application of the doses of prohexadione-calcium commercially recommended to each species.

Ervin and Ok (2001) and Ervin et al. (2002) reported, respectively, 35 and $75 \%$ reductions in chip amounts when trinexapac-ethyl was applied to the plants of Meyer zoysiagrass. Costa et al. (2009), making sequential applications of trinexapac-ethyl at the doses of $55.6+55.6$ and $113+113 \mathrm{~g}$ ai ha ${ }^{-1}$ reported reductions between 49.2 and $55.6 \mathrm{~g}$ ai $\mathrm{ha}^{-1}$ in the total dry mass production by Meyer zoysiagrass plants.

Marchi et al. (2013) verified that the 14 day interval of sequential application of trinexapac-ethyl at the
MARCHI, S. R.; MARTINS, D.; COSTA, N. V.

doses of $113+113,226+226,453+226$, and 904 $+452 \mathrm{~g}$ ai $\mathrm{ha}^{-1}$ or the 14 day interval of sequential application of prohexadione-calcium at $100+100 \mathrm{~g}$ ai ha ${ }^{-1}$ to Meyer zoysiagrass plants resulted in dry mass production reductions superior to $84 \%$ in comparison with the check treatment plants.

The only research work concerning Saint Augustine grass plants found in the literature shows that the sole application of trinexapac-ethyl at $290 \mathrm{~g}$ ai $\mathrm{ha}^{-1}$ resulted in a reduction of $63 \%$ in the total amount of chips in a period of four weeks and that this treatment was not efficient to reduce the emission of floral rachises (McCARTY et al., 2004).

\section{CONCLUSION}

Trinexapac-ethyl at 226, 452, 678 and $904 \mathrm{~g}$ ai $\mathrm{ha}^{-1}$, prohexadione-calcium at 100 and $200 \mathrm{~g}$ ai $\mathrm{ha}^{-1}$, and bispyribac-sodium at $60 \mathrm{~g}$ ai $\mathrm{ha}^{-1}$ were efficient in reducing Saint Augustine grass plants growth and emission of floral rachises. These products are thus recommended to reduce the number of mechanical cutting of the plants for a period of up to $119 \mathrm{DAA}$ and that these treatments cause no deleterious effects to the lawn visual aspect.

RESUMO: Este trabalho teve o propósito de avaliar o efeito da aplicação de três inibidores de desenvolvimento vegetal sobre o crescimento e a emissão de hastes florais da grama-santo-agostinho [Stenotaphrum secundatum (Walt.) Kuntze]. O estudo foi instalado em um gramado com 15 meses de idade, no delineamento de blocos casualizados, com quatro repetições e os tratamentos compostos por aplicação única de trinexapac-ethyl (113, 226, 452,678 e $\left.904 \mathrm{~g}^{\mathrm{ia} \mathrm{ha}}{ }^{-1}\right)$, prohexadione-calcium (100 e $200 \mathrm{~g}_{\text {ia ha }}{ }^{-1}$ ) e bispyribac-sodium (40 e $60 \mathrm{~g}_{\text {ia ha }}{ }^{-1}$ ), além de uma testemunha sem aplicação de inibidor de crescimento. O efeito dos tratamentos foi avaliado quanto à fitointoxicação, por meio de avaliação visual, altura de plantas, altura e emissão de hastes florais e produção total de massa seca de aparas. Todos os inibidores de desenvolvimento vegetal proporcionaram injúrias visíveis sobre a grama-santo-agostinho, mas todos os sintomas de intoxicação praticamente regrediram aos 28 dias após a aplicação. O trinexapac-ethyl aplicado na dose de $904 \mathrm{~g}^{\mathrm{i} a}$ ha ${ }^{-1}$ proporcionou redução de 59,7\% na altura da grama, de 96,4\% e 87,7\% na emissão de hastes florais e na quantidade total de massa seca de aparas produzidas pela grama, respectivamente. Gramados formados com grama-santo-agostinho podem ser manejados com a aplicação de inibidor vegetal, com a redução da necessidade de cortes por um período de até 119 dias após a aplicação, sem efeitos severos sobre o aspecto visual sobre o gramado.

PALAVRA-CHAVE: Stenotaphrum secundatum. trinexapac-ethyl. prohexadione-calcium. bispyribac-sodium.

\section{REFERENCES}

BEAM, J. B. Prohexadione calcium for turfgrass management and poa annua control and molecular assessment of the acetolactate synthase gene in poa апnиа. 2004. 85 p. Thesis. (Doctor Phylosophy in Plant Pathology, Physiology and Weed Science) - Faculty of the Virginia Polytechnical Institute and State University, Blacksburg, Virginia Blacksburg, Virginia, 2004. 
CASLER, M. D.; DUNCAN, R. R. Turfgrass Biology, Genetics, and Breeding. Hoboken, New Jersey: John Wiley \& Sons, 2003. 367 p.

COSTA, N. V.; MARTINS, D.; RODELLA, R.A.; RODRIGUES, A.C.P.; CARDOSO, L.A. Características morfológicas de gramas em resposta a aplicação de trinexapac-ethyl. Planta Daninha, Viçosa, v. 27, n. 1, p. 113-122, 2009.

DUBLE, R. L. Turfgrass: their management and use in the southern zone $-2^{\text {nd }}$ Edition. Texas A\&M University Press, College Station, Texas, 2004. 352 p.

EMBRAPA - EMPRESA BRASILEIRA DE PESQUISA AGROPECUÁRIA. Sistema brasileiro de classificação de solos. Brasília, DF, 2006. 306 p.

ERVIN, E. H.; A. J. KOSKI. Trinexapac-ethyl increases Kentucky bluegrass leaf cell density and chlorophyll concentration. HortScience, Fort Collins, v. 36, n. 4, p. 787-789, 2001.

ERVIN, E. H.; OK, C. H.. Influence of plant growth regulators on suppression and quality of 'Meyer' Zoysiagrass. Journal of Environmental Horticulture, Columbia, v. 19, n. 2, p. 57-60, 2001.

ERVIN, E. H.; OK, C. H.; FRESENBURG, B. S.; DUNN, J. H. Trinexapac-ethyl restricts shoot growth and prolongs stand density of 'Meyer' zoysiagrass fairway under shade. Hortscience, Fort Collins, v. 37, n. 3, p. 502-505. 2002.

ERVIN, E. H., ZHANG, X.; GOATLEY JR., J. M.; ASKEW, S. D. Trinexapac-ethyl, propiconazole, iron and biostimulant effects on shaded creeping bentgrass. HortTechnology, Virginia, v. 14, n. 4, p. 500-506, 2004.

ERVIN, E. H.; ZHANG, W. Influence of sequential trinexapac-ethyl applications on cytokinin content in creeping bentgrass, kentucky bluegrass, and hybrid bermudagrass. Crop Science, Madison, v. 47, n. 5, p. 2145-2151, 2007. http://dx.doi.org/10.2135/cropsci2007.01.0056

FAGERNESS, M. J.; YELVERTON, F. H. Tissue production and quality of 'tifway' bermudagrass as affected by seasonal application patterns of trinexapac-ethyl. Crop Science, Madison, v. 40, n. 2, p. 493-497, 2000. http://dx.doi.org/10.2135/cropsci2000.402493x

FRY, J. D. Centipedegrass response to plant growth regulators. HortScience, Fort Collins, v. 26, n. 1, p. 40-42, 1991.

HECKMAN, N.L.; G.L. HORST, G. L.; GAUSSOIN, R. E. Influence of trinexapac-ethyl on specific leaf weight and chlorophyll content of Poa pratensis. International Turfgrass Society Research Journal, Lincoln, v. 9, n. 4, p. 287-290, 2001.

HECKMAN, N.L.; GAUSSOIN, R. E.; HORST, G. L.; ELOWSKY, C. G. Growth regulator effects on cellular characteristics of two turfgrass species. International Turfgrass Society Research Journal, Lincoln, v. 10, n. 8, p. 857-861, 2005.

JOHNSON, B. J. Influence of frequency and dates of plant growth regulator applications to centipedegrass on seedhead formation and turf quality. HortScience, Fort Collins, v. 15, n. 3, p. 412-416, 1990.

JOHNSON, B. J. Influence of plant growth regulators and mowing on two bermudagrassess. Agronomy Journal, Madison, v. 86, n. 5, p. 805-810, 1994. http://dx.doi.org/10.2134/agronj1994.00021962008600050011x

JOHNSON, B.J. Growth of Tifway bermudagrass following application of nitrogen and iron with trinexapacethyl. HortScience, Fort Collins, v.32, n. 2, p. 241-242. 1997. 
MARCHI, S. R.; MARTINS, D.; McELROY, J. S. Growth inhibitors in turfgrass. Planta Daninha, Viçosa, v. 31, n. 3, p. 733-747, 2013.

MARCHI, S. R.; MARTINS, D.; COSTA, N. V.; SILVA, J. R. V. Effect of plant regulators on growth and flowering of "Meyer" Zoysiagrass. Planta Daninha, Viçosa, v. 31, n. 3, p. 695-703, 2013.

McCARTY, L. B.; WEINBRECHT, L. S.; TOLER; J. E.; MILLER, G. L. St. Augustinegrass response to plant growth retardants. Crop Science, Madison, v. 44, n. 4, p. 1323-1329, 2004.

http://dx.doi.org/10.2135/cropsci2004.1323

McCARTY, L. B.; WILliS, T. G.; TOLER, J. E.; WHITWELL, T. ‘. Agronomy Journal, Madison, v. 103, n. 4, p. 988-994, 2011. http://dx.doi.org/10.2134/agronj2010.0467

McCULLOUGH, P. E.; LIU, H. B., McCARTY, L. B.; WHITWELL, T. Response of 'TifEagle' bermudagrass to seven plant growth regulators. HortScience, Fort Collins, v. 39, n. 7, p. 1759-1762, 2004.

McCULLOUGH, P. E.; LIU, H. B.; McCARTY, L. B.; WHITWELL, T. Bermudagrass putting green growth, color, and nutrient partitioning influenced by nitrogen and trinexapac-ethyl. Crop Science, Madison, v. 46, n. 4, p. 1515-1525, 2005. http://dx.doi.org/10.2135/cropsci2005.08-0286

McCULLOUGH, P. E., LIU, H. B.; McCARTY, L. B.; WHITWELL, T. Growth and nutrient partitioning of 'TifEagle' bermudagrass as influenced by nitrogen and trinexapac-ethyl. HortScience, Fort Collins, v. 41, n. 2 , p. 453-458, 2006.

McCULLOUGH, P. E.; LIU, H. B.; McCARTY, L. B.; TOLER, J. E. Trinexapac-ethyl application regimens influence growth, quality, and performance of bermuda grass and creeping bentgrass putting greens. Crop Science, Madison, v. 47, n. 5, p. 2138-2144, 2007. http://dx.doi.org/10.2135/cropsci2006.04.0256

MITTLESTEADT, T. L.; GOATLEY JR, J. M.; ASKEW, S. D.; HENSLER, K. L.; ASKEW, W. L. Lowimpact conversion of cool-season turf to 'patriot' bermudagrass. International Turfgrass Society Research Journal, Lincoln, v. 11, n. 9, p. 1205-1212, 2009.

REYNOLDS, W. C.; LI, R.; SILVA, K., BRUNEAU, A. H.; QU, R. Field performance of mutant and somaclonal variation lines of St. Augustinegrass [Stenotaphrum secundatum (walt.) kuntze]. International Turfgrass Society Research Journal, Lincoln, v. 11, Section 4, p. 573-582, 2009.

TRENHOLM, L. E.; J.L. CISAR, J. L.; UNRUH, J. B. St. Augustinegrass for Florida lawns. University of Florida. Institute of Food and Agricultural Sciences, Extension ENH 5. Univ. of Florida, Gainesville, FL. 2000. $10 \mathrm{p}$.

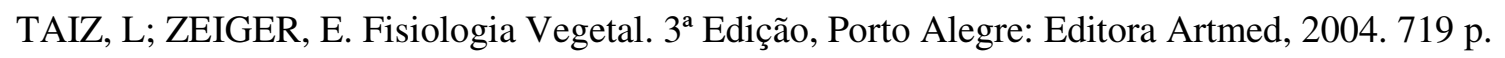

ZHANG, X.; SCHMIDT, R. E.; ERVIN, E. H.; DOAK, S. Creeping bentgrass physiological responses to natural plant growth regulators and iron under two regimes. HortScience, Fort Collins, v. 37, n. 6, p. 898-902, 2002. 